a public supply are the steelworks of Stewarts and Lloyds at Corby, those of Firth Brown at Sheffield and the thread mills of J. and P. Coats at Paisley.

\section{High-Definition Television Transmission}

IN connexion with the high-definition television transmissions which will be radiated from the Alexandra Palace, the British Broadcasting Corporation has requested Baird Television, Ltd,, and Marconi-E.M.I. Television Co., Itd., to send to manufacturers a complete specification of the wave. form which they will radiate in their television transmissions from the palace. We have received from each of the companies their specifications, which are highly technical and will be mainly of interest to manufacturers. The ratio of the horizontal to the vertical breadth of the pictures is four to three for the Baird transmissions and five to four for the E.M.I. transmissions. The latter system transmits 25 complete pictures per second each of 405 total lines. 'These lines are 'interlaced' so that the frame and flicker frequency is 50 per second. It is claimed that good pictures can be received, although only a fraction of the radiated band is used; but the greater the width of the transmitted band utilised the better the received picture.

\section{High Pressure Turbine Practice}

IMPoRTANT developments are taking place in the large power stations of electric supply companies. In the Electrical Times of September 19 there is an interesting account of the Loeffler boilers, which will supply steam turbines at the enormous pressure of 2,000 pounds per square inch. The exhaust steam from the high-pressure turbine is at a pressure of about 195 pounds per sq. in. and is reheated by steam from the boilers before passing into the low-pressure turbine. The North Metropolitan Supply Co. has two stations at Brimsdown called $A$ and $B$. In the old station $A$ the conditions were unfavourable to economical generation as the turbine pressure was only $150 \mathrm{Ib}$. per sq. in. Owing to the favourable economic possibilities offered by the Loëffler boiler the station is being altered; two boilers each having a capacity of $210,000 \mathrm{lb}$. per hour, each operating at a pressure of $2,000 \mathrm{lb}$. per sq. in. and at a total temperature of $940^{\circ} \mathrm{F}$., have been ordered from the Mitchell Engineering Co., Ltd., which has acquired the British rights from the well-known firm of Vitcovice. If petrol drops on the steam pipes at these high temperatures it bursts into flame. About twenty of these boilers are used abroad in Czechoslovakia, Germany and Russia. To get the best results it was necessary to have a set of 50,000 kilowatts. As a machine of this size could not be fitted into Brimsdown $A$ it was divided into two. The high-pressure part has a power of $20,000 \mathrm{kw}$. and the low-pressure part has a power of $30,000 \mathrm{kw}$. It is claimed that certain advantages will accrue from running the machines in series.

\section{The Lower Yield Point of Stress}

The report of the British Association (Section G), Committee on Stresses in Overstrained Materials, presented at Norwich, states that particular consideration has been given to the requirements of the engineering profession and industry in view of present and future developments. By the increasing use of electric and other methods of welding in structural work, the problem of plastic overstrain has reached such high importance as to become one of the determining factors in design, and the Committee puts forward the considered view that the so-called 'lower yield point' affords the most satisfactory and reliable basis for the comparison of structural steels. The several advantages attached to its adoption are set forth seriatim, and a draft specification is submitted. The Committee, of which the chairman is Sir Henry Fowler, expresses the opinion that the lower yield point should be included in the British Standard Specifications, and recommends that the desirability of its addition be brought to the notice of the British Standards Institution.

\section{Publication of Scientific Literature}

THE projects for scientific publication and bibliography (ef. NATURE, 133, 641; 1934) have been implemented by a grant of 15,000 dollars from Chemical Foundation. As a result, a new Documentation Division of Science Service has been initiated in furtherance of activities in this field which were considered at a conference called by Science Service on July 11 and July 29. The immediate objectives being attempted under the grant are the development of camera, projection pointer, reading machine for microphotographs and other means for photographic reproduction, and the establishment of a project for the photographic publication of papers which at present cannot be published promptly or in full. This undertaking will be carried out with the co-operation of existing scientific journals and societies. The plans of the new division are outlined in a paper read by Mr. Watson Davis, director of Science Service, before the thirteenth Conference of the Institut International de Documentation at Copenhagen, September 9-14. It is considered that the scheme for the publication of scientific papers by microphotographic or similar methods should be self-supporting from the start. Possibilities of increasing the availability of existing literature by such methods are to be explored and the broad problem of scientific bibliography is also to be studied.

\section{San Diego Natural History}

Several papers recording new work have been published recently in the Transactions of the San Diego Society of Natural History. Vol. 8(Nos. 6, 7, 8, 9), March 1935, contains a paper on new marine mollusca of West Mexico by Herbert N. Lowe, a description of a new trilobite from Northern California by Harry $\mathrm{E}$. Wheeler, a revision of some Californian Astrodapsis by George L. Richards and some new species of molluses of the genus Triphora by Fred Baker and V. D. P. Spicer. Both the molluse papers deal with the shells alone, but there is in the first a good annotated list of shells collected at Punta Penasco, Sonora, Mexico. The trilobites include a very well preserved specimen 